Article

\title{
Experiencing Religion: Post-Colonial Views for Religious Education
}

\author{
Rito Baring (D)
}

Citation: Baring, Rito. 2022. Experiencing Religion: Post-Colonial Views for Religious Education. Religions 13: 14. https://doi.org/ 10.3390/rel13010014

Academic Editors: Fida Sanjakdar and Liam Francis Gearon

Received: 4 November 2021

Accepted: 21 December 2021

Published: 24 December 2021

Publisher's Note: MDPI stays neutral with regard to jurisdictional claims in published maps and institutional affiliations.

Copyright: (C) 2021 by the author. Licensee MDPI, Basel, Switzerland. This article is an open access article distributed under the terms and conditions of the Creative Commons Attribution (CC BY) license (https:// creativecommons.org/licenses/by/ $4.0 /)$.
Department of Theology and Religious Education, De La Salle University, Manila 0922, Philippines; rito.baring@dlsu.edu.ph

\begin{abstract}
Framed within religious historicism, the present study reviews, through historical and empirical insights, the lessons that Philippine RE can learn from the liberating function of religion and liberated religious undercurrents parallel to institutional religion in the Philippines. The liberating function of religion is often overlooked in post-colonial discourses while religious undercurrent views seem neglected due to pre-occupations with untangling power imbalances submerged in the voices of institutional religion in post-colonial analysis. Hence, in this presentation, I give particular attention to the liberating role of contemporary religion in contrast to the post-colonial thrust to rid institutional religion of power and control and secondly, the liberated religious views of young Filipino audiences from empirical findings I found from my previous studies. For religious undercurrents, I limit myself to current unorthodox religious interpretations of young Filipino audiences departing from conventional assumptions of religion and culture. My analysis of liberating religion and liberated religious views from empirical findings show epistemological shifts from the Christian interpretation in a post-colonial context. These shifts point to de-institutionalized but theocentric religious ideas inspired by moral and communal considerations, which form the basis of RE content.
\end{abstract}

Keywords: post-colonial; religious education; religion; Filipino youth; Filipino religiosity

\section{Introduction}

For a significant period of time in Europe, Christianity formed the "cultural and ethical" (Llorent-Bedmar and Cobano-Delgado 2014, p. 50) backbone of society. In three Nordic countries, Religious Education (RE) is compulsory (Llorent-Bedmar and CobanoDelgado 2014). This has significant bearing on how the Christian mindset impacts European daily life and perspectives. This appears to be the case in the Philippines. Like Europe, Philippine RE's preoccupation with the Christian metanarratives appears to have cemented altogether its anchor on the western story and epistemological abstractions. However, Religious Education in the Philippines is unique in many ways from its European or western counterparts. Western RE is largely educating about faiths in the plural sense. Instruction in western RE is not exclusively confessional, with the exception of Canada where distinctions between catechesis (faith) and religious education (cognitive training) appears to be blurred (Rymarz 2011). In contrast to most European arrangements, Philippine RE is confessional, hence, anchored largely on catechesis (Baring 2011, 2015) and of living the faith. RE is not a compulsory course in the curriculum. Being oriented towards confessional religion, Philippine RE serve as a mouthpiece of religious tradition by articulating faith and values grounded in the gospel imperative.

Being different from western RE does not mean Philippine RE has carved an identity independent of the influences of western Christianity. Unlike Europe, the Filipino integration of Christian ideas in socio-cultural and ethical life came with colonization. The reception of faith for the Filipinos coincided with subjugation by a foreign power. Years after colonization, religious and cultural diversity have grown significantly in the country. However, this diverse climate seems relegated to the sidelines in RE instruction, understandably due to the dominance of Christianity in the country. In addition, recent studies 
point to revealing patterns of new religious engagements and shifting views with regard to faith and values (Baring 2018). New patterns of beliefs can be discerned from emerging viewpoints. With new religious challenges unfolding today, RE needs to connect with the lessons of current religious experiences. As an instrument of religion, RE needs to radically engage "with a plurality of voices and perspectives that have been historically marginalized and silenced" (Nye 2019, p. 5). Local RE's preoccupation with the preset voices associated with domination and influence behind the Christian narrative is at stake when we attend to RE's noble mission of forming mindset. The context of Philippine RE is such that a growing awareness of diversity in cultures, worldviews, and religion (Baring 2011) necessitate specific attention towards how RE might address the growing diversities while attending to values and faith formation. Such commitment places RE in the forefront as an instrument of transformation and growth. Being exploratory, my presentation will utilize relevant historical and empirical sources that challenge assumptions about religion and culture following religious historicism as a framework. Historicism emphasizes the central function of history as a critical determinant of knowledge. Hence, recourse to history is relevant to deconstruction. Through a historical frame the religious and cultural assumptions of RE can be deconstructed (Copley 1998). Viewed under empirical realism, religious historicism (Inge 1936) or theological empiricism (Dean 1990) can commit to deconstructive analysis through an analysis of religious history through events and evolving epistemologies. Over and above the debatable points underneath the concept (van den Akker 2021), historicism in my view affirm that cultural experiences are the result of historical unfolding which situate every evolving concept. In my paper, historicism (Fullerton 1987) implies that events or phenomena (e.g., perceived positive influence of religion and revised religious notions) are influenced by certain conditions available in history (e.g., liberating function of religion and liberated religious undercurrents representing epistemological shifts in religious ideas). In applying religious historicism, I examine the evolving patterns of religious experiences and phenomena, which are themselves "contingent, historically situated, and non-universal concepts" (Lynch 2012, p. 13).

In this presentation, I will focus on the liberating function of religion and liberated religious undercurrents running parallel to institutional religion using historical insight and recent empirical findings I previously gathered from young Filipino audiences. In historical presentations, religion is introduced either as a delimiting or liberating institution. Its delimiting function show religion's varied instrumentality as a tool of subjugation, compulsion, and control. On the other hand, the liberating function of religion speaks magnanimously about religion's contemporary social engagements. Liberation Theology, which arose in late 20th century and is associated with the Latin American movement, outlines this liberating thrust (Boff and Boff 1987). Religion's liberating function upholds that for which religion is being criticized-human dignity and freedom. In the past, institutional submission to power and subjugation appears to have toned down this function. Religion is liberating when it highlights the transformative effect of faith (Sands 2018) more than the compelling impact of colonization and exclusion for which religion is made an instrument. Recent notable pronouncements include the Christian exhortation to care for the earth, which emphasizes the compelling commitment of faith to conserve, preserve, and protect the earth's resources (Molino 2019). The call for solidarity among nations with attention towards the marginalized raises the voice for more inclusive programs and strategies. These and many other examples exemplify the enduring appeal of inclusive religious ideals. On the other hand, liberated religious undercurrents are free religious ideas not endorsed officially by official religion, hence, unhindered by institutional expectations. An undercurrent religious view in the present analysis includes religious ideas patronized by a community that does not essentially subscribe either to orthodox institutional mindsets or traditional religious views. These are alternative expressions of faith. Alternative faith expressions not subscribing to official faith expressions at times are associated with subversion (Agence France-Presse 2019). In the case of the Philippines, historical narratives suggest that Filipinos under colonial rule have greatly absorbed western religious practice 
and thinking under Spanish and American impositions. Spanish rule brought the Christian faith (Robertson 1918) and organized mass conversions. The Americans brought Protestant Christianity and "produced a strong ideological and institutional legacy for State-Church relations in postcolonial Philippines" (Batalla and Baring 2019, p. 3). However, this perceived internalization of the Christian faith appears to have taken a variety of local appropriations today. Contemporary Filipino Christians may be characterized as active (visibly engaged), passive (de-institutionalized), and indifferent (unchurched). Recent field data refers to a downtrend in church involvement, hence, making active members close to only half the population (SWS 2017). The active cluster represent various memberships from among popular devotees (Sapitula 2014), the silent and organized worshippers including those who patronize institutionally organized online worship. The passive members still claim institutional religious affiliation but are not religiously involved while maintaining personal ideas about worship and belief. The passive members are a growing population of Christians who interpret faith not from western categories but from personal experiences. Their interpretation ran parallel to popular interpretations but do not equally reflect popular piety since they are not equally active or regular worshippers. The indifferent group is a very small group of religious 'nones' declaring disaffiliation comprising about two percent of the population. It is from the passive group that the present study looks at religious undercurrents. The present study voices parallel cognitive trajectories suggesting that variant epistemologies are emerging from among various sectors, particularly the youth as a unique form of localized re-appropriation. These ideas reflect latent sentiments from the field often neglected by scholarship because they are not literally articulated in the public sphere.

\section{Pre-Colonial and Colonial Contexts}

Before, during, and after colonization, the archipelago was highly multi-cultural and religiously diverse. Indigenous religions abound in various communities. When the archipelago was colonized, the colonizers covered mostly affiliated communities, which were Christianized under the "bajo de campana" (literally, bell base) rule of Spanish rulers (Fernandez 1979). Under this rule, authorities govern settlements within hearing distance from the bell mostly situated at the center of a municipality. However, despite this arrangement there were people in the peripheries not 'included' in the 'Bajo de Campana' rule of local parishes centered around municipal powers. These excluded small groups lived in cultural and religious diversity. They lived 'outside' the church in silence and lived their lives according to their customs. For instance, those who were not Christianized performed their own rituals when burying their dead (Arcilla 2000). Their dead cannot be buried inside the public cemeteries, which by then were already controlled by Spanish authorities (Aure 2004).

In this context, it can be said that two systems were operative: the imposed official rule of Spanish leadership and the informal indigenous rule of unbaptized indigenous inhabitants (Fitzpatrick 2013). Throughout Spanish rule, the undercurrent rule of indigenous communities co-existed with the dominant Spanish presence. Indigenous religions lived side by side the Christian religion.

Since RE is about living the faith, this historical view suggests that a post-colonial reflection of Philippine RE should review the Pre-colonial religious dispensation since it anchors the original state of affairs of people's religious mindset before impositions of power took place. Secondly, the sustained undercurrent of indigenous religious views during colonization already showed the resilience of underground or unofficial religious mindsets, which is not far from our current RE context. Historical accounts showing how these undercurrents survived can shed light about how indigenous worldviews and attitudes, and recently nuanced usages of faith in our time, grew unimpeded from imposed power structures or metanarratives. These can show how patterns of uncolonized mindset were lived and articulated. 
Having determined that the vestiges of Spanish colonization were facilitated and promoted by the introduction of formal religion side by side Christian incursions of the indigenous mindset, we wonder, how might religion have contributed towards a liberating social life besides serving a metanarrative of colonization? To answer the question, I will use historical and empirical insights from my previous studies to show how liberating religious inspirations moved people to action and how unorthodox religious ideas run parallel to institutional religion in colonial and post-colonial times in the country. The liberating effect of religion and religious undercurrents testify to the enduring relevance of religious insight beyond the dictates of delimiting narratives that only promote power oriented cliches.

\section{Lessons from History: Gift of Religion}

Historians traditionally identify Christianity as a tool for Spanish colonization (Rafael 1988; Hernandez 2010). Hence, religion in this regard is considered an instrument of oppressive force/power. Colonization refers to European/western rule and impositions on colonized territories. The process of colonization, as experts admitted, "did not end with political independence" (Nye 2019, p. 7). The declaration of independence only formalized the loosening of structures imposed upon a people. Independence clandestinely gave way to internal colonizers, the ruling elite in particular, gradually making their impositions upon the weaker classes. Hence, critiques insist that the process of colonization is an unfinished business still taking place in the contemporary world. Going side by side, the historical view of Christianity being enmeshed in symbols of power and domination is another historical view of religion presented as a tool for liberation. Reynaldo Ileto's work Pasyon and Revolution (Ileto 1979) cited how religion can also be an instrument of the liberation of people. With the rise of nationalistic sentiments during the later years of Spanish occupation, Filipino natives fought the colonizers with inspiration from religious convictions (Sturtevant 1976; Gealogo 2010) citing the Aglipayan rebellion. It was said that the hanging of the three secular priests known in history as GomBurZa (Reyes Churchill n.d.) inspired later nationalistic sentiments. Such inspiration grew in conversation with liberal ideas and advanced with progressive ideas lately in recent post-colonial studies conversing with feminism, biblical exegesis, and liberation theology (Donaldson and Pui-Lan 2016). Dialoguing with contemporary local events as praxis, religious inspiration and imagination were intense in the crucial moments of the first EDSA bloodless people power revolution in 1986 when people were called to EDSA in Metro Manila, which led to the overthrow of an oppressive Marcos regime (Reyes 2018). While separation of church and state is enshrined in the 1987 Philippine Constitution, religion in peacetime Philippines invoke serious initiatives to counter gross violations of human dignity and human rights. The harsh criticisms lodged by President Rodrigo Duterte against the Catholic Church did not stop the church from pursuing its mission (Batalla and Baring 2019). Religion contributes significantly to mass movements, conscientization and mobilization of civil society groups for political, environmental, and cultural advocacies. Hence, drawing from these examples, the religious history of the Philippines under colonial rule and post-colonial context expresses two contrasting poles with respect to power-as instrument for colonization and stimulant for liberation and change.

\section{Reappropriating Religious Ideas: Post-Colonial Turn}

The liberation fueled by religion in local history provided the seedbed that nurtures and supports religious ideas. Religion appears to present a different version of its presence in today's world. New religious perspectives interpreted by some as popular versions of Christianity has evolved through the years. In addition, recent religious views developing from underneath mainstream religion and distinct from popular religious variants also make their way in recent local studies. A case in point is a recent investigation into Filipino youth attitudes towards the environment (Baring et al. 2021b), which reveal a uni-dimensional theocentric construct distinct form the usual religious viewpoints. This 
construct emphasizes the role of God as creator of the world, sanctity of nature and human moral responsibility. It departs from popular anthropocentric views or indifferent views vis a vis the environment. This recent empirical finding from a previous study I did is also distinguished from traditional environmental views anchored on developmental grounds. Due to their unique trajectories (Baring et al. 2021b) coming from the field, these religious views emerge in unique ways side by side theologies endorsed by institutional religion, and theological views of independent theological scholars. The theologies behind local empirical studies of student views uncover revealing religious undercurrents that represent peculiar views towards the sacred among others. Their emerging epistemologies show unorthodox, non-traditional interpretations of religious ideas. These local empirical findings see religious ideas (not institutional religion) as a resource for cultural and religious empowerment. Religious ideas are currently re-appropriated by Filipino stakeholders, especially the youth as a material for free expression in various fields like the environment, politics, and culture. The general pattern showing the movement towards de-institutionalized but recalcitrant theocentric belief represent a post-colonial turn or departure from Eurocentered religious moorings and inaugurate an era of religious discernment for localized Christian worldviews. For instance, we see how youth informants' notions move away from the typical binary appreciation of the sacred and profane then introduced by Emile Durkheim (1915) and the far and distant 'holy' introduced by Rudolf Otto ([1923] 1936). While previously Durkheim saw the sacred as something set apart and forbidden, youth re-appropriations of the sacred is expanded to include unexpectedly moral and communal considerations (Peracullo et al. 2019). In traditional Christianity, the attributes attached to the sacred belongs to institutional consecration, which often determines the sanctity of words, places, objects, and the like. The sacred character of the altar is recognized by institutional consecration and dedication (Hamilton and Spicer 2006). Sacramentals are sacred because of the blessing pronounced by the priest towards the object or place. In contrast, radical youth religious views not only depart from institutional language but also put aside the role of consecration or blessing to what is considered sacred. Their views reflect shared inclusive values and behavioral patterns that characterize belief in specific communities. The sustained culture behind these peculiar interpretations of faith throughout the country suggest deep-seated appreciations of faith not endorsed previously by official Christianity or of western categories. In De Mesa's (2000) view, Filipino popular devotions mirror Filipino primal religions. Primal religious beliefs are linked to traditional popular notions of religion showing personal affinities with the sacred (Baring 2018). This attribution of religious meanings goes as far as assigning transactional appreciations of faith (Baring and Erasga 2021). Echoing Mercer's view (Mercer 2009), these parallel manifestations of unofficial faith running side by side religious orthodoxy imply that ever since, indigenous religious interpretations never faded but only took a parallel route. Second, the traditional western categorization of the religious-spiritual binaries now finds a different re-appropriation among the youth as a fused construct "Spiritual/Religious" instead of the spiritual and religious notion (Baring 2018) in religious studies. Third, youth attitudes towards religion express deep sentiments of connectedness with the divine introduced in western constructs as the 'other'. The religious 'other' is unfortunately marked as a means to perpetuate colonial discourse on dominance and power. The 'other' is also a representation of differences and disconnect when representing variations of interpretations on the sacred between Christian denominations. The western category of the religious other such as Rodolf Otto's classic idea of the 'holy' as a notion that cannot be reduced to ethical and rational epistemologies imputes distance and impersonal relationships. In contrast, the youth affirm emotional security and emotional commitment towards God, rejecting relational detachment and hollow abstractions about God. Youthful emotions in this respect are an engaged disposition not indifferent to religious feedback. This explains why youth attitudes comfortably communicate the locus of the sacred in communal life or sense the supernatural being within the temporal order. The religious other is communicated by youth informants' unconventional religious views (Baring et al. 2018) and 
environmental attitudes (Baring et al. 2021b) as motivating factor and personally engaging voice. Whether it is for religion (Baring 2018), global citizenship (Baring et al. 2021a), or the environment (Baring et al. 2021b), Filipino youth audiences from my previous studies show de-institutionalized but theocentric religious ideas inspired by moral and communal considerations. Data coming from a large State University in Southern Philippines, which we analyzed (Baring et al. 2021a), with a predominant Muslim enrollment, consistently show students' religious attitudes being engaged with life issues and pro-social commitments. Indeed, religion's functional significance in social life remains high in the face of increasing influences of secular life.

\section{Conclusions}

Post-colonial researchers agree that education in general is a locus of the struggle for identity. Philippine RE shares this dilemma since values formation is not detached from identity formation. In the present study, historical elements play significantly with the formation of mindsets. Learning from the empirical shifts analyzed in the foregoing essays, it appears that decolonizing Philippine RE necessitate raising questions driven by diverse voices and locating the epistemological center of newfound ideas. While analysis and promotion of indigenous language is usually advanced as a material for discourse analysis towards decolonization, the present paper proposes a different route towards decolonization through an exploration of changing mindsets and worldviews unimpeded by authority and power-driven language. The vibrant life behind unspoken religious undercurrents is a wellspring of undefined ideas not tempered by institutional expectations but nevertheless echo authentic voices from the ground. This is to address the lack of voice noted in RE discourse which can be attributed largely to predefined content that follows cultural systems promoting power imbalances instead of promoting indigenous epistemologies that reflect diverse voices and stories. The local field is rich with mindsets and worldviews waiting to be tapped. Apparently, there is an inevitable shift towards lived religion as a cohesive representation of personal narratives of faith instead of merely drawing from religious metanarratives. This seems to be the order in which RE can facilitate the interpretation of new experiences. An initiative such as this encourages knowledge production separate from the suspicious framing of ideas beholden to universalized western biases and western values. In addition, an imbalance in epistemological explorations between academic programs and school context is noted. Our empirical examples from previous studies show that much of RE content introduce Eurocentric centering in their articulation introduced as a default in most schools (Gearon 2020). For Gearon, decolonizing RE points to ridding the curriculum of its colonial imprints and re-orienting the self.

Overall, these historical instances and empirical shifts show how the liberating function of religion and liberated religious undercurrents challenge traditional articulations of religion and culture and in the process unmask the resilience of religious undercurrents operant in Philippine RE. The epistemological shifts demonstrated by these undercurrents offer the following lessons for RE: First, the re-appropriations of religious concepts propose a contextual and inculturated understanding of values and behavior against alienating behavioral patterns and shared morals. Second, RE is encouraged to promote a different sense of religious other cleared of the symbols of control, exclusivity, and domination. It also means loosening its patronage of gendered mindsets towards religion, environment, and spirituality by promoting equity, equality, and communion. Finally, feeling the voices of the unofficial marginal sectors, RE is better off loosening itself from marginalizing tendencies or ahistorical views by emphasizing inclusion, sensitivity to local culture, and empowerment of the minority. The rising consciousness towards the liberating role of religion and liberated religious ideas now challenge Catholic schools to reframe the place of Religious Education as a formative instrument. 
Funding: This research received no external funding.

Institutional Review Board Statement: Not applicable for studies not involving direct human or animal participation. Sources of analysis are drawn from findings in previous studies.

Informed Consent Statement: Not applicable. There was no direct human participation for this study.

Data Availability Statement: Not applicable.

Conflicts of Interest: The author declares no conflict of interest.

\section{References}

Agence France-Presse. 2019. West Using Christianity to Subvert Chinese State: Official. ABS-CBN News. Available online: https://news.abs-cbn.com/overseas/03/12/19/west-using-christianity-to-subvert-chinese-state-official (accessed on 21 December 2021).

Arcilla, José S., ed. 2000. The Zamboanga-Basilan-Jolo Mission. In Jesuit Missionary Letters from Mindanao. Quezon City: University of the Philippines, vol. 2.

Aure, Bonn. 2004. Archaeological Inference and Another Look at Junker's Mass Burial. Philippine Quarterly of Culture and Society 32: 161-77.

Baring, Rito. 2011. Plurality in Unity: Challenges towards religious education in the Philippines. Religious Education 106: $459-75$.

Baring, Rito. 2015. The State of Religious Education in the Philippines: A Review of Literature. Hapag 12: 142-63.

Baring, Rito. 2018. Emerging transitions in the meaning of religious constructs: The case of the Philippines. Religions 9: 387. [CrossRef]

Baring, Rito, and Dennis Erasga. 2021. Purchase(d) spirituality and transactional belief in religious practice: Attributes of a popular faith-based Filipino devotion. In Western and Eastern Perspectives on Religion and Religiosity. Edited by Sarah Demmrich and Ulrich Riegel. Munster: Waxmann Verlag, pp. 79-98.

Baring, Rito, Francisco Magno, Stephen Reysen, and Iva Katzarska-Miller. 2021a. Student religious attitudes and global citizenship antecedents, identification, and outcomes in a Filipino sample. Journal of Beliefs \& Values, 1-12. [CrossRef]

Baring, Rito, Jeramie Molino, and Stephen Reysen. 2021b. The Development and validation of the Christian Environmentalism scale from a Philippine sample. Journal of Empirical Theology. Advance online print. [CrossRef]

Baring, Rito, Philip Joseph Sarmiento, Nestor Sibug, Benita Bonus, Paolo Lumanlan, Cristina Samia, and Stephen Reysen. 2018. Filipino College Students' Attitudes towards religion: An analysis of the underlying factors. Religions 9: 85. [CrossRef]

Batalla, Eric Vincent, and Rito Baring. 2019. Church-state separation and challenging issues concerning religion. Religions $10: 197$. [CrossRef]

Boff, Leonardo, and Clodovis Boff. 1987. Introducing Liberation Theology. New York: Orbis Books.

Copley, Terence, ed. 1998. RE Futures: A Reader in Religious Education. Derby: CEM.

De Mesa, José M. 2000. Primal religions and popular religiosity. East Asian Pastoral Review 37: 1-7.

Dean, William. 1990. Empirical Theology: A Revisable Tradition. Process Studies 19: 85-102. Available online: https://www.religiononline.org/article/empirical-theology-a-revisable-tradition/ (accessed on 20 July 2021). [CrossRef]

Donaldson, Laura, and Kwok Pui-Lan, eds. 2016. Postcolonialism, Feminism and Religious Discourse, 1st ed. Oxfordshire: Taylor and Francis.

Durkheim, Emil. 1915. Elementary Forms of the Religious Life. Translated by Joseph Ward Swain. London: George Allen \& Unwin Ltd.

Fernandez, Pablo. 1979. History of the Church in the Philippines (1521-1898). Manila: Life Today Publications.

Fitzpatrick, Christine. 2013. Religion and Spanish Colonialism in the Philippines. Unpublished Thesis, University of Wisconsin-La Crosse, La Crosse, WI, USA. Available online: https:/ / minds.wisconsin.edu/bitstream/handle/1793/66613/Fitzpatrick_Thesis. pdf?sequence $=1$ (accessed on 20 July 2021).

Fullerton, Ronald. 1987. Historicism: What It Is, and What It Means For Consumer Research. In NA-Advances in Consumer Research Volume 14. Edited by Melanie Wallendorf and Paul Anderson. Provo: Association for Consumer Research, pp. 431-34.

Gealogo, Francis. 2010. Time, Identity, and Nation in the "Aglipayan Novenario ng Balintawak" and "Calendariong Maanghang". Philippine Studies 58: 147-68. Available online: http:/ /www.jstor.org/stable/42632051 (accessed on 30 August 2021).

Gearon, Liam. 2020. Religious education and the pandemic: Postcolonial perspectives. British Journal of Religious Education 43: 9-22. [CrossRef]

Hamilton, Sarah, and Andrew Spicer. 2006. Defining the Holy: Sacred Space in Medieval and Early Modern Europe. London: Routlege.

Hernandez, Jose Rhommel. 2010. Reduccion: Ang Pag-uwi sa Diskurso ng Pananakop at Pakikipagtunggali. Malay 23: 67-80.

Ileto, Reynaldo. 1979. Pasyon and Revolution. Quezon City: Ateneo de Manila University Press.

Inge, William Ralph. 1936. Historicism and religion. History 20: 289-302. Available online: http://www.jstor.org/stable/24401083 (accessed on 23 July 2021).

Llorent-Bedmar, Vicente, and Veronica Cobano-Delgado. 2014. The Teaching of Religious Education in Public Schools in the Nordic Countries of Europe. Review of European Studies 6: 50-57. [CrossRef]

Lynch, Gordon. 2012. The Sacred in the Modern World. London: Oxford University Press.

Mercer, Leigh. 2009. Review: Frontier Constitutions: Christianity and Colonial Empire in the Nineteenth-Century Philippines by John D. Blanco. Philippine Studies 57: 579-81. Available online: http://www.jstor.org/stable/42634029 (accessed on 30 August 2021). 
Molino, Jeramie. 2019. Engaging Pope Francis' Laudato Si in the Discourse on Environmental Communication. Bangkok: Religion and Social Communication.

Nye, Malory. 2019. Decolonizing the Study of Religion. Open Library of Humanities 5: 1-45. [CrossRef]

Otto, Rudolf. 1936. The Idea of the Holy. Oxford: Oxford University Press. First published 1923.

Peracullo, Jeane, Rito Baring, Elenita Garcia, Lars Raymund Ubaldo, and Dennis Erasga. 2019. The Sacred experiences of Filipino youth. In Young People and the Diversity of (non) Religious Experiences in International Perspective. Edited by Elizabeth Arweck and Heather Shipley. Basel: Springer Publications Inc., pp. 131-47.

Rafael, Vicente L. 1988. Contracting Colonialism: Translation and Christian Conversion in Tagalog Society Under Early Spanish Rule. Quezon City: Ateneo de Manila University Press.

Reyes Churchill, Bernardita. n.d. History of the Philippine Revolution. Available online: http:/ / www.ncca.gov.ph/about-culture-andarts/articles-on-c-na/article.php?igm=2\&i=190 (accessed on 30 August 2021).

Reyes, Portia. 2018. Claiming History: Memoirs of the Struggle against Ferdinand Marcos's Martial Law Regime in the Philippines. Sojourn: Journal of Social Issues in Southeast Asia 33: 457-98. Available online: https://www.jstor.org/stable/26538540 (accessed on 12 November 2020). [CrossRef]

Robertson, James. 1918. Catholicism in the Philippine Islands. The Catholic Historical Review 3: 375-91. Available online: http: //www.jstor.org/stable/25011532 (accessed on 30 August 2021).

Rymarz, Richard. 2011. Catechesis and Religious Education in Canadian Catholic Schools. Religious Education 106: 537-49.

Sands, Justin. 2018. Transforming the Conversation: What is liberation and from what is it liberating us? A critical response to "Transforming encounters and critical reflection: African thought, critical theory, and liberation theology in dialogue". Religions 9: 194. [CrossRef]

Sapitula, Manuel Victor. 2014. Marian piety and modernity: The Perpetual help devotion as popular religion in the Philippines. Philippine Studies 62: 399-424. [CrossRef]

Social Weather Station-SWS. 2017. First Quarter 2017 Social Weather Survey: 48\% of Filipino Adults Attend Religious Services Weekly; 85\% Said Religion Is Important. Available online: https://www.sws.org.ph/swsmain/artcldisppage/?artcsyscode=ART-201704 13105521 (accessed on 7 May 2018).

Sturtevant, David R. 1976. Popular Uprisings in the-Philippines, 1840-1940. Ithaca: Cornell University Press.

van den Akker, Chiel, ed. 2021. The Routledge Companion to Historical Theory, 1st ed. London: Routledge. [CrossRef] 